Original Research

\title{
Knowledge, Family Support and Self-Reliance Capital when Caring for Low Birth Weight Babies
}

\author{
Erlina Suci Astuti ${ }^{1}$, Nursalam Nursalam ${ }^{2}$, Shrimarti Rukmini Devy ${ }^{1}$ and Risa Etika ${ }^{3}$ \\ ${ }^{1}$ Faculty of Public Health, Universitas Airlangga, East Java, Indonesia \\ 2 Faculty of Nursing, Universitas Airlangga, East Java, Indonesia \\ ${ }^{3}$ Department of Neonatology, Dr. Soetomo General Hospital Surabaya, East Java, Indonesia
}

\section{ABSTRACT}

Introduction: Low birth weight (LBW) infants are very susceptible to illness. LBW treatment with the principle of preventing infection is very important at home. The purpose of this study was to determine the relationship between maternal knowledge and family support with the prevention of infection at home.

Methods: This study used a correlation design. The samples were 160 mothers who had low birth weight infants with inclusion criteria mothers give birth to babies weighing less than 2,500 grams with ages 0-2 months. The samples were obtained through purposive sampling. The dependent variable was the mother's ability to prevent infection while the independent variable was the mother's knowledge and family support. The instruments used were questionnaires. This research analyzed using Spearman Rho.

Results: The results showed that there was a strong correlation between knowledge and the ability to prevent infection in treating low birth weight $(\mathrm{r}=$ 0.696; $p=0.00$ ) and that there was a moderate correlation between family support and infection prevention ability when treating a low birth weight $(r=0.54 . \mathrm{p}=$ $0.000)$.

Conclusion: Factors of maternal knowledge about infection prevention and family support need to be considered in increasing the ability of mothers to care for babies with LBW. The factor of maternal knowledge about prevention of infection has a strong correlation value when compared to family support factors. Further research is needed on the model of increasing maternal knowledge about LBW infants during home care.
\end{abstract}

\section{ARTICLE HISTORY}

Received: April 10, 2019

Accepted: May 29, 2019

\section{KEYWORDS}

low birth weight; family support; knowledge; independence of the mother

\section{CONTACT}

Nursalam Nursalam $\triangle$ nursalam@fkp.unair.ac.id $\ggg$ Faculty of Nursing, Universitas Airlangga East Java, Indonesia

Cite this as: $\quad$ Astuti, E. S., Nursalam, N., Devy, S. R., \& Etika, R. (2019). Knowledge, Family Support and Self-Reliance Capital when Caring for Low Birth Weight Babies. Jurnal Ners, 14(1), 10-15. doi:http://dx.doi.org/10.20473/jn.v14i1.12734

\section{INTRODUCTION}

Low birth weight (LBW) babies are babies born with a body weight of less than 2,500 grams. The number of low birth weight infants in Indonesia is also quite high. Riskesdas in 2013 showed that the percentage of low birth weight of infants was $10.2 \%$. The birth rate of low birth weight infants in East Java was $11.2 \%$, which is slightly higher than the national figure (RI Ministry of Health, 2014; WHO, 2014). The high prevalence of low birth weight babies in Java, especially East Java because in addition to the large population resulting in a high number of births, the culture of women in Java as workers to help the family economy where most respondents have less family income, fatigue due to work, psychological conditions, maternal age at pregnancy and maternal nutritional factors during pregnancy.

The physiological condition of low birth weight has an impact on various health problems that arise such as hypothermia, the lack of ability to consume nutrients and infection (RI Ministry of Health, 2010; World Health Organization, 2011; Akter, Dawson and Sibbritt, 2016).

Infection and sepsis are health problems related to a low birth weight during the neonatal period that can lead to death. The incidence rate of infection in the neonatal period can reach $17 \%$ (respiratory infections) and the incidence rate of sepsis can reach $22 \%$. Low birth weight babies are the second leading 
cause of neonatal death in Indonesia, which is $32 \%$ (RI Ministry of Health, 2014).

The survey results in hospitals in Malang, East Java, found that $10.4 \%$ of the total LBW infants treated in the Perinatology room were LBW infants who experienced re-hospitalization, meaning that after returning from the neonatology room before they were one-month-old, the baby had to be hospitalized again because of serious health problems. Health problems that often occur in LBW infants are being febrile, infection, dehydration, shortness of breath, vomiting, and diarrhea.

The health condition of a low birthweight after returning from home care must be maintained properly. Mothers, as the primary care providers for LBW, must be able and independent both in knowledge, attitude and actions when it comes to caring for their babies, especially in terms of the prevention of infection.

The ability and independence of the mother in treating LBWs is determined by their knowledge, mental readiness and skills when carrying out baby care. The results of the research showed that the mother's knowledge about the care of the baby at home found that the mother's knowledge in relation to the effort to prevent infection was $44.45 \%$ with less knowledge (Rita et al., 2008). Infection is the main cause of death in LBW infants. Infection in LBWs at home can be due to the inability of the mothers to care for babies cleanly, as well as environmental factors such as exposure to infection in both the human and living environment. The risk of infection in LBWs is also due to the body's immunity factor which is still lacking. The body is not able to defend itself against any infections that enter the body.

Mothers who have LBW babies often experience obstacles in relation to carrying out their roles. One of the obstacles is family support. Family support is very important when the mothers experience role changes, stress and further care problems when at home (Singer et al., 2017; Jilian Ireland et al., 2016; Mehler et al., 20 14).

Mothers need knowledge, information and care support from the environment from both health and family officers in the first 6 months after birth (Warren, 2005). Family support is very important in order to improve the ability and confidence of the mothers in caring for babies However, family support in relation to the care of LBW babies is sometimes less than optimal. Dewi Purwanti et al (2012), in her study, said that family support for independence and the role of mothers when caring for LBW babies was less supportive (53\%).

A lack of maternal knowledge about LBW, an unstable psychological condition and LBW conditions that require special care and family support will all have an impact on the ability of the mothers when it comes to caring for LBW. LBW treatments that are not particularly good at preventing infection will cause the babies to get sick.

The purpose of this study was to provide information on maternal knowledge about the prevention of LBW infection and its relationship with family support and the ability of the mothers to prevent infection.

\section{MATERIALS AND METHODS}

This study used a correlation research design that explains the relationship between knowledge and family support with the ability of the mothers to prevent infection when treating an infant with LBW. This research was conducted between September to November 2018 in Malang, East Java. This study involved 160 respondents obtained by purposive sampling from 190 respondents. The inclusion criteria were mothers who gave birth to LBW babies (body weight less than 2,500 grams with a baby aged 0-2 months and infants without any congenital defects). The dependent variable was the mother's ability to provide infection care while the independent variable was the mother's knowledge and family support.

The data was obtained through a questionnaire. The demographic data was assessed using one item that covered age, education, employment, childbirth history related to a previous low birth weight infant, family income and information on low birthweight care. The data was measured using a closed questionnaire. The mother's knowledge of preventative care for their infant was measured using a modified questionnaire on low birth weight care (Ministry of Health, 2014). Ten questions were used to assess family knowledge related to the definition, causes, signs and symptoms, ways and effects of the prevention of infection when treating LBW babies. The scale of the data in this questionnaire was ordinal with 1 (less) to 3 (good). The family support variable instrument was compiled based on a measurement questionnaire by Gareth D. Mercer (2015) with modifications adjusted to fit families who had infants with low birthweight.

This instrument consisted of statements about information support, assessment, instrumentality or means, emotional support and social network support with an ordinal data scale from 1 (less) to 3 (good). The instrument of the ability of the mothers to take preventive measures was measured through observations and interviews based on LBW care books and health manuals (Ministry of Health of the Republic of Indonesia, 2016; Ministry of Health, 2010) with 6 items focused on maternal activities. The collected data was categorized into ordinal data scales from 1 (less) to 3 (good).

All instruments were tested for validity and reliability in a pilot study consisting of 15 respondents. Each item in the statements had validity ( $r>0.529$ ) and each questionnaire also achieved reliability $(>0.8)$.

Descriptive analysis was used for the characteristics of the respondents. The analysis of the relationship of the dependent variables independently was done using Spearman Rho with a statistical significance level set at $\mathrm{p}<0.05$. Ethical 
clearance was provided by the Faculty of Public Health ethics team number 504- KEPK on September 3rd, 2018.

\section{RESULTS}

\section{Characteristics of the Respondents}

The characteristics of the respondents have been presented in Table 1 . The majority of respondents were aged between 20 and 35 years old. The most common education obtained was that of junior high school. The job of housewife was the most common The monthly family income was most commonly less

Table 1. Characteristics of the Respondents

\begin{tabular}{lcc}
\hline \multicolumn{1}{c}{ Variable } & n & \% \\
\hline Age & 14 & 8.8 \\
<20 years old & 115 & 71.9 \\
20-35 years & 31 & 19.4 \\
$>$ 35 years old & & \\
Education & 40 & 25.0 \\
$\quad$ Elementary school & 57 & 41.9 \\
$\quad$ Junior high school & 38 & 23.8 \\
$\quad$ senior high school & 15 & 9.4 \\
$\quad$ College & & \\
Work & 10 & 6.3 \\
$\quad$ Farmer & 42 & 26.3 \\
Laborers & 24 & 15.0 \\
$\quad$ Employers & 84 & 52.5 \\
Housewife & & \\
Family Income & 63 & 39.4 \\
$\quad<1$ million & 76 & 47.5 \\
1-2 million & 20 & 12.5 \\
3-5 million & 1 & 0.6 \\
$\quad>5$ million & & \\
History of low birthweight & 101 & 63.1 \\
$\quad$ Yes & 59 & 36.9 \\
No & & \\
Information about low birthweight & & \\
care & & \\
Yes & 92 & 57.5 \\
No & 68 & 42.5 \\
\hline
\end{tabular}

Table 2. Description of the Variables

\begin{tabular}{lcccc}
\hline \multicolumn{1}{c}{ Variable } & $\mathbf{n}$ & $\mathbf{\%}$ & Mean & SD \\
\hline Independent & & & & \\
Knowledge & & & 2.75 & 0.49 \\
$\quad$ Well & 126 & 78.8 & & \\
$\quad$ Enough & 29 & 18.1 & & \\
$\quad$ Less & 5 & 3.1 & & \\
Family support & & & 2.73 & 0.49 \\
$\quad$ Well & 92 & 57.5 & & \\
$\quad$ Enough & 58 & 36.3 & & \\
$\quad$ Less & 10 & 6.3 & & \\
Dependent & & & & \\
Ability to prevent & & & 2.73 & 0.49 \\
infection & & & & \\
$\quad$ Well & 122 & 76.3 & & \\
$\quad$ Enough & 34 & 21.3 & & \\
$\quad$ Less & 4 & 2.5 & & \\
\hline
\end{tabular}

Table 3. Spearman Rho Analysis

\begin{tabular}{lcc}
\hline \multicolumn{1}{c}{ Variable } & $\begin{array}{c}\text { Correlation } \\
\text { Coefficient }\end{array}$ & $\begin{array}{l}\text { Sig. (2- } \\
\text { tailed) }\end{array}$ \\
\hline Knowledge -ability & 0.696 & 0.000 \\
Family support -ability & 0.540 & 0.000 \\
\hline
\end{tabular}

than Rp. 2.000 .000 . Most of the respondents had had children with a previous low birthweight.

\section{Description of the Variables}

The description of the variables has been explained in Table 2. The average maternal knowledge about the prevention of infection in neonates was 2.75 (SD = 0.49). The average family support felt by the respondents was 2.51 (SD $=0.61$ ). The ability of the mother to prevent infection when treating LBWs at home averaged $2.73(\mathrm{SD}=0.49)$.

\section{Variable Correlation}

The calculated correlation between infection prevention and the ability to treat an infant with a low birth weight as well as the correlation between family support and infection prevention care for infants with a low birth weight. The test results show that there was a relationship between family support and infection prevention in LBWs $(r=0.54 ; p=0.000)$. There is a relationship between a low birth weight and the prevention of care and between family support and infection prevention for low birth weight infants (Table 3). The test results show that there was a relationship between family support and infection prevention ability $(\mathrm{r}=0.54 ; \mathrm{p}=0.000)$.

\section{DISCUSSION}

Knowledge is the basic foundation of behavior. The knowledge of baby care for mothers is very important so then the mothers are able to care for their babies well. The research findings showed that in relation to the mothers' knowledge of infection prevention, $78.8 \%$ at a good level and the practice of infection prevention in caring for babies was also good at $76.3 \%$. The results of good knowledge from $78.8 \%$ of the respondents showed that the awareness of and willingness to seek out information in the sample of mothers who had LBW infants was very high because $42.5 \%$ of respondents did not get the information needed.

The results of extracting information when the data was collected were obtained even though the mother had not received good information regarding LBW care from the health workers. When preparing to go home, not all hospitals did a good discharge planing method of low-weight baby care at home obtained from the results of the questionnaire, only some mothers received the information from the sick hospital who cared for it, not all mothers during treatment waited for their singers first allowed to go home while their baby is still in the hospital so if there is counseling at home the baby does not know. Almost all mothers had mobile communication media access that enabled access to the internet in addition to asking neighbors or relatives who had given birth for help. This data is known when interviewing data retrieval mothers have cellphones with internet services.

The mothers consider that information about baby care is the main requirement for postpartum 
mothers (Arzani et al., 2015; Slomian et al., 2017). There are four postpartum maternal needs, namely: information needs, psychological support needs, the need to share experiences and practical and material support needs. A mother needs more and sometimes different information from other mothers because they sometimes have a different focus on the problems that can arise (Misgna, Gebru and Birhanu, 2016; Slomian et al., 2017).

Less knowledge will make the mother feel confused and not know what to do to care for her baby. This condition will make the mothers stressed and even depressed. The stressful condition of the mother will disrupt their daily activities, including the task of caring for the baby (Offiah, O'Donoghue and Kenny, 2012). The results of the research that supports this was conducted in Canada. It found that the mothers of premature babies experience increased levels of psychological stress that is more severe in the neonatal period than mothers of fullterm infants.

The confusion, stress and anxiety of mothers stands out when they are discharged from the hospital (Singer et al., 2017) This psychological pressure will be weighed on by the family environmental factors, such as a low family income and a large number of family members that are dependent on the same pool of living costs (Suplee, Gardner and Borucki, 2014). The results of this study indicate that $86.9 \%$ of the respondents came from families with an income of less than 2 million per month, which is an income level far from the regional minimum wage of Malang (2.7 million / month).

The mother's knowledge was, overall, relatively good, even though some of the mothers had not received information about LBW care at home supported by the experience factor of having a low birth weight baby before and their age. The results showed that $63.1 \%$ of respondents had a history of giving birth to LBW infants beforehand, so that they were familiar with the health conditions and care of LBW babies. The age of the respondents in this study was that $71.9 \%$ were of a productive age or they were women of childbearing age who had the duty to care for their children.

The health information in this study was partly provided by the health workers (57.5\%). Correct information about LBW care both during childbirth and on their return to the hospital from a health worker in charge of the community will increase the level of maternal knowledge. Visits by community health workers have been shown to increase the interaction and communication of mothers and health workers so then they are able to solve any baby health problems well, especially in the first month (Horowitz et al., 2013).

Health education has been shown to increase the mother's confidence in caring for her baby (Gilmer et al., 2016). Babies with problems or high-risk babies are vulnerable groups who must get special care and assistance such as visits so then the mothers are not too stressed and are able to independently care for their babies (Haugan, Innstrand and Moksnes, 2013).

This is done because LBW babies have serious problems regarding the risk of infection, their lack of nutrient intake and hypothermia. Infections that arise as a result of poor treatment, such as not washing one's hands properly when treating a baby, avoiding exposure to infection at home, using non-sterile devices for direct care, sterile cord care etc. can trigger infection and sepsis (Rice, 2001; Marilyn and Wong, 2004; Yadav, Chaudhary and Shrestha, 2011).

The results of the study show that the knowledge of mothers about the prevention of infection in LBWs has a significant effect $(p=0,000)$ on the ability of the mothers to prevent infection in relation to the care of their babies. Village midwives actively provide counseling and assistance. The results related to maternal knowledge were that $18.1 \%$ had sufficient knowledge and that $3.1 \%$ were incompetent, which means that the baby has the potential for infection and illness. This is in accordance with Boykova and Kenner's (2012) study which found that $30 \%$ of LBW babies will experience pain after being taken care of at home. The high birth rate of LBWs and premature babies puts a burden on the parents and also creates a public health burden because of the impact of morbidity and mortality (Offiah et al, 2012).

Family support is something that cannot be ignored in relation to helping the cognitive and behavioral abilities of the mother to care for her baby. The family support given to the mother to care for her baby is given the most by the biological mother or mother-in-law who lives close to the mother of the baby, support by the husband, especially in the nuclear family. Support for the mother is not given as whole care but it is very helpful for the mother to care for her baby. The biggest support is psychological support for funds to provide baby care facilities. A family atmosphere that is harmonic, that fulfills the material needs of the mother, that is involved in infant care and that provides support for other treatments will improve the mother's psychology. Mothers, in both the antenatal and postpartum period of ten, do not feel that they are informed enough about this difficult part of their life span; they need support from their family. They feel that they are not sufficiently supported, not only from a psychological point of view but also from a more practical perspective. For example, this can include help with domestic work. Mothers need to share their life experiences, they need to be convinced and they need to feel understood. Family support is done by providing for the needs of the mother and trying to prevent the risk of postpartum psychological distress during the postpartum period (Hookway and Everson, 2011; Ingram et al., 2016).

The results showed that family support for mothers who carried out LBW care at home was 57.5, which is good, with there being a number of significant relationships from maternal behavior to preventing infection in the medium category. In carrying out the role of a mother, a harmonious 
relationship between husband and mother-baby and with other family members is the most important factor (Alligood, 2014).

Family support increases people's confidence. The family is a source of power that is owned by the family in order to regulate their values, communication patterns and the role of the family as a lifestyle. This is so then the families are able to carry out their functions well (Friedman, 2003).

The results showed that the treatment and behavior required to prevent infection in infants was $76.3 \%$, and therefore was at a good level. Good care and the supervision of LBW babies is derived from knowledge and family support. This shows that the preparation for the transition from the hospital setting is quite good. Preparation for this period still requires commitment from the health workers, mothers and their families (Murch and Smith, 2016).

Monitoring the condition of the baby and mentoring the mother is very important in order to maintain a conducive situation for the health of LBW babies and their mothers (Schönbauerová and Boledovičová, 2015; Mahanta et al., 2016).

\section{CONCLUSION}

Factors of maternal knowledge about infection prevention and family support need to be considered in increasing the ability of mothers to care for babies with low birth weight. The factor of maternal knowledge about prevention of infection has a strong correlation value when compared to family support factors. Further research is needed on the model of increasing maternal knowledge that is optimal so that babies with low birth weight do not have health problems during home care.

\section{REFERENCES}

Akter, T., Dawson, A. and Sibbritt, D. (2016). "The determinants of essential newborn care for home births in Bangladesh'.Public Health. 141, pp. 7-16. doi: 10.1016/j.puhe.2016.08.004.

Alligood, M. R. (2014).Nursing Theorists and Their Work. St. Louis, Missouri. doi: 10.5172/conu.2007.24.1.106a.

Arzani, A. et al. (2015). 'Mothers' strategies in handling the prematurely born infant: a qualitative study'.Journal of caring sciences, 4(1), pp. 13-24. doi: 10.5681/jcs.2015.002.

Boykova, M. and Kenner, C. (2012). 'Transition From Hospital to Home for Parents of Preterm Infants'. The Journal of Perinatal \& Neonatal Nursing, 26(1), pp. 81-87. doi: 10.1097/JPN.0b013e318243e948.

Friedman, M. M. (2003).Family Nursing research, Theory \& practice, fifth edition. New Jersey: Pearson Education, Inc.p.

Gareth D. Mercer B.Sc. (2015). 'Do fathers care? Measuring mothers' and fathers' perceptions of fathers' involvement in caring for young children in South Africa by', (July), pp. 1-295.

Gilmer, C. et al. (2016). 'Parent education interventions designed to support the transition to parenthood: A realist review'.International Journal of Nursing Studies, 59, pp. 118-133. doi: 10.1016/j.ijnurstu.2016.03.015.

Gray, P. H. et al. (2013). 'Parenting stress in mothers of very preterm infants - Influence of development, temperament and maternal depression'.Early Human Development, 89(9), pp. 625-629. doi: 10.1016/j.earlhumdev.2013.04.005.

Haugan, G., Innstrand, S. T. and Moksnes, U. K. (2013). 'The effect of nurse-patient interaction on anxiety and depression in cognitively intact nursing home patients'.Journal of Clinical Nursing, 22(15-16), pp. 2192-2205. doi: 10.1111/jocn.12072.

Hookway, L. and Everson, B. (2011). 'First familycentred care coordinators appointed to support families through the difficult and stressful time of having a baby in neonatal care'.Journal of Neonatal Nursing, 17(6), pp. 216-218. doi: 10.1016/j.jnn.2011.09.004.

Horowitz, J. A. et al. (2013). 'Nurse home visits improve maternal/infant interaction and decrease severity of postpartum depression'.JOGNN - Journal of Obstetric, Gynecologic, and Neonatal Nursing, 42(3), pp. 287300. doi: 10.1111/1552-6909.12038.

Ingram, J. C. et al. (2016). 'Does family-centred neonatal discharge planning reduce healthcare usage? A before and after study in South West England', pp. 1-10. doi: 10.1136/bmjopen-2015010752.

Jilian Ireland, Minesh Khashu, Luisa Cescutti-Butler, Edwin van Teijlingen, J. H.-T. (2016). 'Experience of father with babies admitted to neonatal care units'.Journal of Neonatal Nursing. doi: dx.doi.org/10.1016/j.jnn.2016.01.006.

Kementerian Kesehatan RI. (2010).Buku Saku Pelayanan Kesehatan Neonatal Esensial.

Kementerian Kesehatan RI. (2014).Profil Kesehatan Indonesia Tahun 2013. satu, Jakarta: Kementerian Kesehatan RI. satu. Edited by M. E. drg. Vensya Sitohang, M. Dr. drh. Didik Budijanto, M.Kes Boga Hardhana, S.Si, and M. K. A. drg. Titi Aryati Soenardi. Jaakarta. doi: 351.770.212 Ind P.

Kementrian Kesehatan Republik Indonesia. (2016).Buku Kesehatan Ibu dan Anak, Buku Kesehatan Ibu dan Anak. doi: 362.198.2.Ind b.

Lakshmanan, A. et al. (2017). 'The impact of preterm birth $<37$ weeks on parents and families : a crosssectional study in the 2 years after discharge from the neonatal intensive care unit'. Health and Quality of Life Outcomes, pp. 1-13. doi: 10.1186/s12955-017-0602-3.

Mahanta, T. G. et al. (2016). 'Effectiveness of introducing home-based newborn care (HBNC) voucher system in Golaghat District of Assam'.Clinical Epidemiology and Global Health, 4(2), pp. 69-75. doi: http://dx.doi.org/10.1016/j.cegh.2015.08.002.

Marilyn, H.-E. and Wong, L. D. (2004).Wongs clinical manual of pediatric. 6th edn. St. Louis, Missouri: Mosby. 
Mehler, K. et al. (2014) 'Increased rate of parental postpartum depression and traumatization in moderate and late preterm infants is independent of the infant's motor repertoire', Early Human Development, 90(12). doi: 10.1016/j.earlhumdev.2014.09.008

Misgna, H. G., Gebru, H. B. and Birhanu, M. M. (2016). 'Knowledge, practice and associated factors of essential newborn care at home among mothers in Gulomekada District, Eastern'.BMC Pregnancy and Childbirth, pp. 1-8. doi: 10.1186/s12884-0160931-y.

Murch, T. N. and Smith, V. C. (2016). 'Supporting Families as They Transition Home'.Newborn and Infant Nursing Reviews, 16(4), pp. 298-302. doi: 10.1053/j.nainr.2016.09.024.

Offiah, I., O'Donoghue, K. and Kenny, L. (2012).Preterm Birth - Mother and Child. doi: $10.5772 / 1284$.

Rice, R. (2001).Home Care Nursing Practice, concepts and application. 3th ed. St Louis, Missouri: Mosby Year Book.

Riset, B. and Dasar, K. (2012). 'Dukungan sosial keluarga dan hubungannya dengan kecemasan ibu primipara dalam merawat bayi berat badan lahir rendah', pp. 249-254.

Rita Magdalena br, Tarigan, Restuning Widiasih, E. (2008). 'Pengetahuan ibu tentang penatalaksanaan perawatan bayi bblr di rumah di rskia kota bandung', pp. 1-15.

Schönbauerová, A. and Boledovičová, M. (2015). 'The role of paediatric nurse in home visiting of newborns and infants in the past - Literary survey'.Kontakt, 17(4), pp. e211-e218. doi: 10.1016/j.kontakt.2015.09.003.

Singer, L. T. et al. (2017). 'Parenting Stress After the Birth of a Very Low-Birth-Weight Infant', 281(9), pp. 799-805.

Slomian, J. et al. (2017). 'Identifying maternal needs following childbirth: A qualitative study among mothers, fathers and professionals'. BMC Pregnancy and Childbirth, pp. 1-13. doi: 10.1186/s12884-017-1398-1.

Suplee, P. D., Gardner, M. R. and Borucki, L. C. (2014). 'Low-Income, Urban Minority Women's Perceptions of Self- and Infant Care during the Postpartum Period'Journal of Obstetric, Gynecologic \& Neonatal Nursing, 43(6), pp. 803812. doi: 10.1111/1552-6909.12506.

Warren, P. L. (2005). 'First-time mothers: Social support and confidence in infant care'.Journal of Advanced Nursing, 50(5), pp. 479-488. doi: 10.1111/j.1365-2648.2005.03425.x.

WHO. (2014). 'WHA Global Nutrition Targets 2025: Low Birth Weight Policy Brief'.W.H.O Publication, pp. 1-7. doi: WHO/NMH/NHD/14.3.

World Health Organization. (2011). 'Guidelines on optimal feeding of low birth-weight infants in lowand middle-income countries.'Geneva: $W H O$, pp. 16-45.

Yadav, D. K., Chaudhary, U. and Shrestha, N. (2011). 'Risk factors associated with low birth weight.'Journal of Nepal Health Research Council, 9(2), pp. 159-164. doi: https://doi.org/10.33314/jnhrc.v0i0.266

Widhiarso, W. (2005). Mengestimasi Reliabelitas. Fakultas Psikologi UGM. Yogyakarta. 